WOODS HOLE OCEANOGRAPHIC INSTITUTION
Woods Hole, Massachusetts

REFERENCE NO. 67-38

STRUCTURE OF THE WESTERN SOMALI BASIN

by

Elizabeth T. Bunce, M. G. Langseth, R. L. Chase, and M. Ewing

JuTy 1967

TECHNICAL REPORT

Submitted to the Ocean Science and Technology Group, Office of Naval Research under contract Nonr-4029(00) NR 260-101.

Reproduction in whole or in part is permitted for any purpose of the United States Government. In citing this report in a bibliography, the reference given should be to the "Journal of Geophysical Research, Vol. 72, No. 10, May 1967, pp. 2547-2555."

Distribution of this document is unlimited.

Approved for Distribution Keysalsen T. Bunce

E. T. Bunce

Acting Department Chairman

Dept. of Geology \& Geophysics 


\title{
Structure of the Western Somali Basin ${ }^{1}$
}

\author{
Elizabeth T. Bunce, ${ }^{2}$ M. G. Langseth ${ }^{3}$ R. L. Chase, ${ }^{2}$ and M. Ewing ${ }^{3}$
}

\begin{abstract}
The western Somali Basin in the northwestern Indian Ocean is covered by thick deposits of terrigenous sediments. Seismic reflection profiles show, however, the northern and southern parts to be very different. The northern sections is a deep basin filled with thick uniformly stratified sediments. It is enclosed by the continental margin to the west and north, Chain ridge to the east, and shallow basement structure to the south. A change in depth of basement occurs along an approximately east-west line at latitude $3^{\circ} 30^{\prime} \mathrm{N}$ very near the southern end of Chain ridge. In the southern portion of the basin the basement is shallow, and, immediately south of latitude $3^{\circ} 30^{\prime} \mathrm{N}$, it has high relief. Stratified flat-lying sediments fill the basement depressions, and isolated hills formed of basement material rise above the abyssal plain deposits. Farther to the south the abyssal plain becomes very narrow. Gabbro dredged from the southeast slope of Chain ridge has been dated by the potassium-argon method as $89.6 \pm 4.5 \mathrm{~m} . y$., which should be considered a minimum age. The evidence suggests that the entire sediment sequence of the northern basin was deposited subsequent to the formation of the ridge. The thin sediment cover of the southern portion of the basin is probably no older than Tertiary.
\end{abstract}

\section{INTRODUCTION}

The Somali Basin, in the northwestern Indian Ocean, is partially enclosed by the coast of Africa to the west and northwest and by the Carlsberg ridge to the east and northeast. Its southern boundary is taken as an east-west line through the Comores Islands and northern tip of Madagascar, the Seychelles bank, and the flanks of the mid-ocean ridge (Figure 1). The basin is divided into eastern and western parts. The western basin, which includes the Somali abyssal plain, is bounded to the east by Chain ridge and several less prominent structures, oriented approximately north northeast-south southwest, extending from the region of the Owen fracture zone [Matthews, 1963, 1966] to Madagascar.

During August 1963 the R.V. Vema of Lamont Geological Observatory made three crossings of the western Somali basin. In April 1964 the R.V. Chain of the Woods Hole Oceanographic Institution, participating in the International Indian Ocean Expedition, traversed the basin from the continental rise south of Socotra

1 Woods Hole Oceanographic Institution Contribution 1855 and Lamont Geological Observatory Contribution 1037.

2 Woods Hole Oceanographic Institution, Woods Hole, Massachusetts 02543 .

${ }^{3}$ Lamont Geological Observatory, Columbia University, Palisades, New York 10964. to the Seychelles bank. The pertinent tracks are shown in Figure 1. Parts of the traverse by Chain were planned to investigate in detail structures found during Vema's crossings and the earlier British geophysical investigations conducted from H.M.S. Owen and R.R.S. Discovery [Admiralty Marine Science Publications, 1963, 1966; Anonymous, 1964].

Both Vema and Chain conducted continuous measurements of the gravity and magnetic field intensity and bathymetry. Continuous seismic reflection profiles were obtained over the entire track of Vema and over a major portion of Chain's track. Cores and heat flow measurements were obtained by both vessels, and rock was dredged from the southeast slope of Chain ridge by Chain.

Gravity and magnetic measurements aboard Vema were obtained by a Graf sea gravimeter and a Lamont Geological Observatory proton precession magnetometer; aboard Chain a LaCoste-Romberg sea gravimeter and a Varian proton-precession magnetometer were used and the data computed by a shipboard IBM 1710 computer [Bowin et al., 1965]. The continuous seismic profiler (CSP) [Hersey, 1963; Bunce and Hersey, 1966] aboard Chain was used throughout with the 100,000 -joule sparker, operated at a repetition rate of $10 \mathrm{sec}$, as sound source and a towed Chesapeake hydrophone array as receiver. 


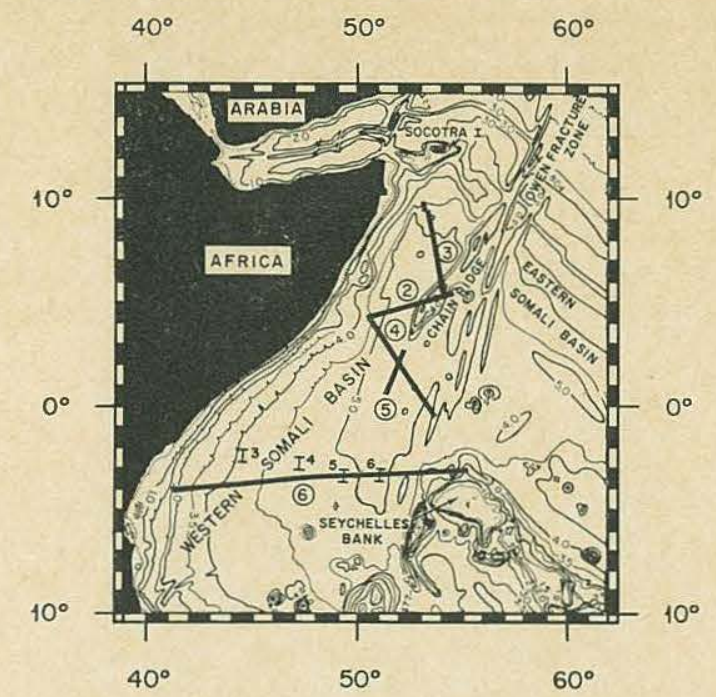

Fig. 1. Bathymetry of the Somali basin showing location of observations. Drafted on a portion of the bathymetric sketch accompanying the physiographic diagram of the Indian Ocean, published by the Geological Society of America. (Copyright 1964 by B. C. Heezen and M. Tharp. Reproduced by permission.) Contours in kilometers. Circled numbers refer to profiles of Figures $2-6$, uncircled numbers, to refraction profiles reported by Francis et al. [1966].

The Vema profiles were obtained by the technique of seismic profiling described by Ewing and Tirey [1961]. One-half pound explosive charges detonated at 1-min intervals were used as source and a Lamont Geological Observatory EEL was towed as receiver.

This paper presents the geophysical data and proposes an interpretation of the structure of the western Somali basin based on these data.

\section{Geophysical Results}

Geophysical evidence presented here suggests a natural structural division of the western Somali basin into two sections, northern and southern. The northern section extends from the continental rise south of Socotra to near latitude $3^{\circ} 30^{\prime} \mathrm{N}$. Two profiles cross this section. The southern section between latitude $3^{\circ} 30^{\prime} \mathrm{N}$ and the Comores Island chain is traversed by four profiles. The investigations reported here are limited to the basin north of $4^{\circ} \mathrm{S}$.

Northern section. The Vema profile (Figure 2) crosses the abyssal plain from east to west, from Chain ridge to a small ridge east of the
Somali continental slope. The Chain profile (Figure 3) starts in the north on the slope of a seamount near the base of the continental rise, angles southeast and east, then turns south to traverse the abyssal plain to Chain ridge.

The echo-sounding records show several continuous reflectors in the upper 20 meters of sea floor material. This shallow stratification is observed on the continental rise. It becomes clearly defined and can be traced continuously in the abyssal plain as well as southwest of Chain ridge. Both the number of layers and their clear definition diminish toward the southeast margin of the plain.

The significant features of the reflection profiles are the total thickness and the lateral uniformity of layering of the sediments covering the floor of the abyssal plain. The sediments are about 2 sec (two-way reflection travel time) thick near the continental rise at the northern margin of the plain and reach a maximum thickness of $2.2 \mathrm{sec}$ near the foot of the small ridge on the western margin (Figure 2). It is possible to identify three zones of different reflective properties on this profile (Figure 2). The uppermost sequence, 0.65 to 0.75 sec thick, is strongly stratified. Although its thickness appears remarkably uniform across the basin, it does increase gradually to the east and north. Below this sequence is acoustically transparent sediment showing little or no stratification; i.e., there are few reflecting interfaces. The equivalent sequence on the profile of Figure 3 shows some stratification in this region. This difference may be more apparent than real, possibly caused by the difference in profiling methods and recording resolutions of the two systems [Bunce and Hersey, 1966].

In the profile of Figure 2 the transparent layer thickens toward the continent to the west. The thickening results from the abrupt deepening of the deepest reflector which dips down toward the ridge only partially crossed by the track. The upper portion of the acoustically transparent sequence is continuous with layers that slope upward on the ridge and thin toward its top. The sediment on the slope is less stratified than the upper zone of the basin but is more clearly stratified than the sequence forming the acoustically transparent layer. The material forming the ridge gives strong reverberant returns and shows no stratification. 


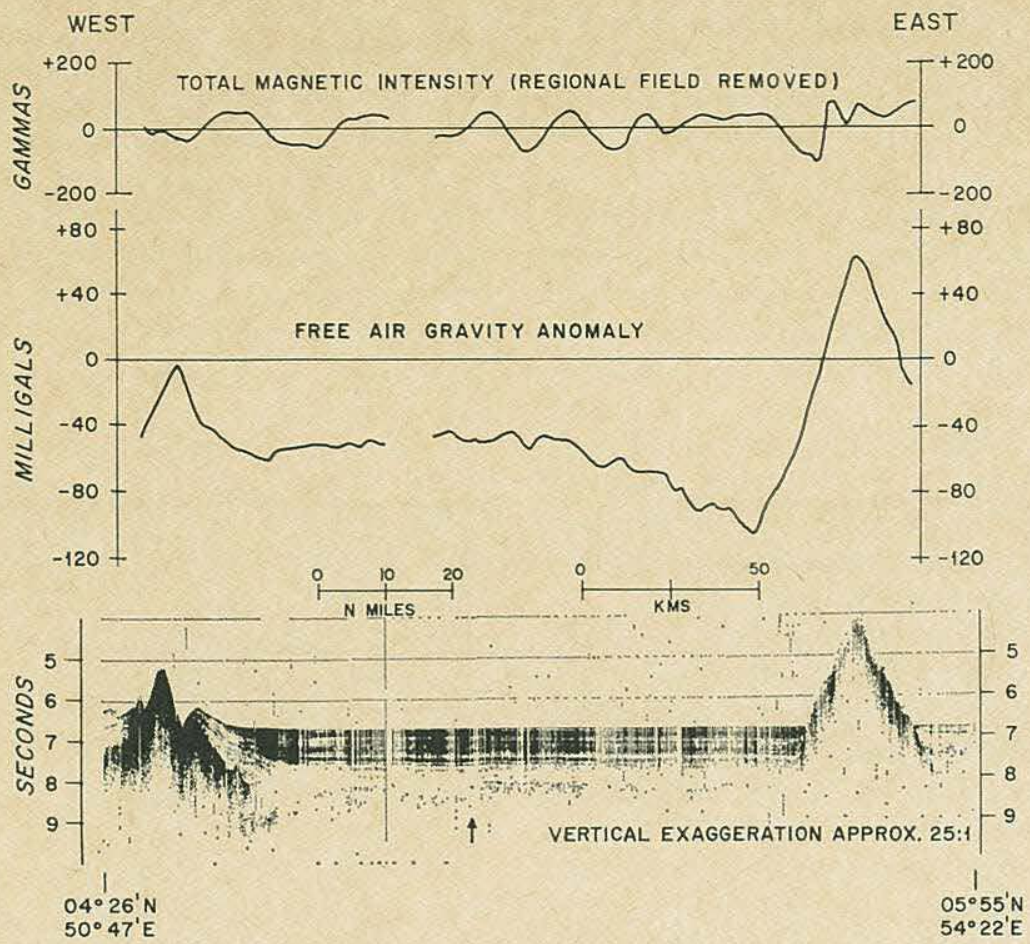

Fig. 2. Northern Somali basin. East-west crossing of Vema. Total magnetic intensity (regional variation removed), free-air gravity anomaly, and seismic reflection profile. The vertical scale of the reflection profiles of Figures 2-6 is expressed as seconds of two-way travel time. To convert this to meters knowledge of the compressional wave velocity of the layers is necessary. An approximate value for sea water is $1500 \mathrm{~m} / \mathrm{sec}$.

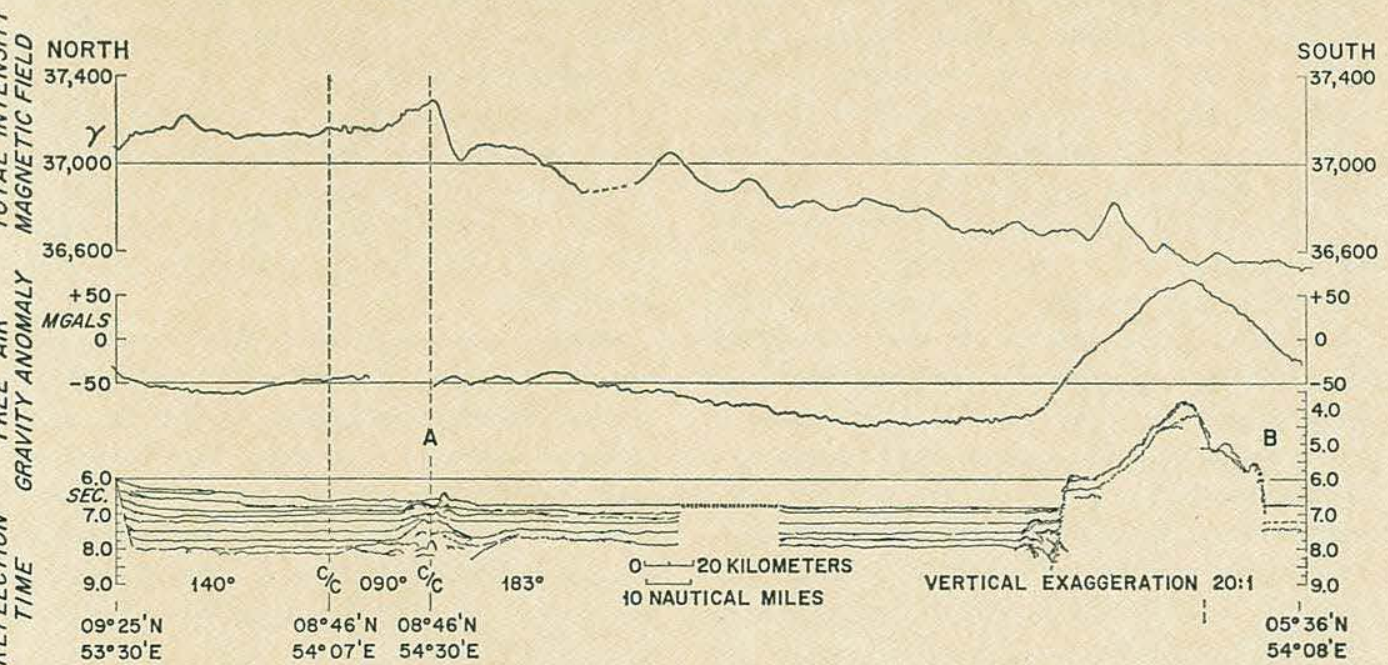

Fig. 3. Northern Somali basin. North-south traverse of Chain. Total magnetic intensity, free-air gravity anomaly, and seismic reflection profile. Ship heading and course changes shown, lower left. (Modified from Bunce et al. [1966, Figure 2].) 
The profile of Figure 3 shows the sediments thickening gradually toward the north. At point $A$ in the profile the flat-lying layers are disturbed near the foot of a partially buried hill.

To the east, the northern portion of the basin is bounded by the Chain ridge. The uppermost highly stratified sediments, $0.5 \mathrm{sec}$ or approximately 500 meters thick, terminate abruptly against the ridge structure, whereas the deeper layers are disturbed and appear to turn up so as to conform with the ridge slope. This is more clearly seen in Figure 2. Because of the large vertical exaggeration of the figures, the steep appearance of this ridge on the reflection profiles is misleading, its average slope being slightly more than $5^{\circ}$ on several crossings.

The magnetic profile along the essentially north-south track (Figure 3 ) shows undulations superposed on the regional trend. The east-west profile (Figure 2), from which the regional trend has been removed, is also undulating in character. These variations may be due to high relief or variation in directions of magnetization of the basement that underlies the thick sediments but is not observed on the seismic profiles. An anomaly of approximately 200 gammas is found on the crossing of Chain ridge, a lower value than might be expected for a volcanic feature at this latitude.

Rocks were dredged from the southeastern slope of the ridge near $5^{\circ} 36^{\prime} \mathrm{N}, 54^{\circ} 02^{\prime} \mathrm{E}$, in the profiler depth interval between 4.75 and $6.5 \mathrm{sec}$, or 3200 - and 4700 -meter water depth (Figure 3, B). About twenty-five fragments of rock were hauled aboard, the largest of which weighed about $3 \mathrm{~kg}$. The fragments comprised fresh gabbro, gabbro in various stages of alteration to clay minerals, and soft light-brown clay with numerous tubular pores, partially coated with manganiferous material. A potassium-argon radiogenic age of $89.6 \pm 4.5$ m.y. was determined from a pyroxene concentrate from the fresh gabbro by J. A. Miller and R. Grasty of the Department of Geodesy and Geophysics, Cambridge University (J. Cann, personal communication). A chemical analysis of the gabbro, which will be published at a later date, shows it to have the normative composition of an olivine tholeiite. Incipient alteration of the pyroxene and development of small amounts of nontronite seen in this section suggests that escape of argon may have taken place since initial crystallization. Thus the age of $89.6 \pm$ $4.5 \mathrm{~m} . \mathrm{y}$. should be considered a minimum, and the gabbro is at youngest of Cretaceous age.

Southern section. Three reflection profiles traverse this area of the basin. One crosses from the ridge on the western margin southeast toward the Seychelles (Figure 4), the second runs south-southwest from Chain ridge (Figure $5)$, the third crosses the basin from the Seychelles bank to the coast of Kenya at Mombasa (Figure $6 a$ and $6 b$ ). These profiles show that the structure differs markedly from that of the northern basin. The rough basement surface is buried beneath relatively thin sediment deposits. The vertical relief varies by 0.5 to $1 \mathrm{sec}(1-2 \mathrm{~km})$. The depressions in the basement topography have been filled by stratified sediment forming an abyssal plain in the sentral part of the basin through which some of the basement hills protrude. The sediment of the sea floor is finely stratified, as in the northern section, and is probably continuous with it.

The sediments near the slope of the small ridge on the western margin of the basin (Figure 4, right-hand side) are stratified but are neither flat lying nor always conformable with the basement structure. About $50 \mathrm{~km}$ from this ridge the basement is not detected, and the profile suggests that it may drop off rapidly. A negative free-air gravity anomaly of about 80 mgal associated with this small area and a twodimensional Bouguer calculation [Talwani et al., 1959] show that the basement probably lies no deeper than $2 \mathrm{~km}$.

The eastern margin of the abyssal plain is clearly defined topographically by a small but abrupt upward change in bottom slope. The depth to basement decreases gradually east of this slope break, and the sediments thin to 0.25 sec or less.

Except for the anomaly already described, the gravity field is smooth along the profile, the free-air anomaly decreasing toward the southeast to a value of $-20 \mathrm{mgal}$. The variation in magnetic intensity increases from northwest to southeast along the profile, perhaps corresponding to the rising basement. A 300 -gamma anomaly is observed over the marginal structure east of the slope break.

The profile south of Chain ridge (Figure 5) crosses the track of Figure 4 near $1^{\circ} 50^{\prime} \mathrm{N}$, $52^{\circ} 10^{\prime} \mathrm{E}$. It shows the characteristically rough 

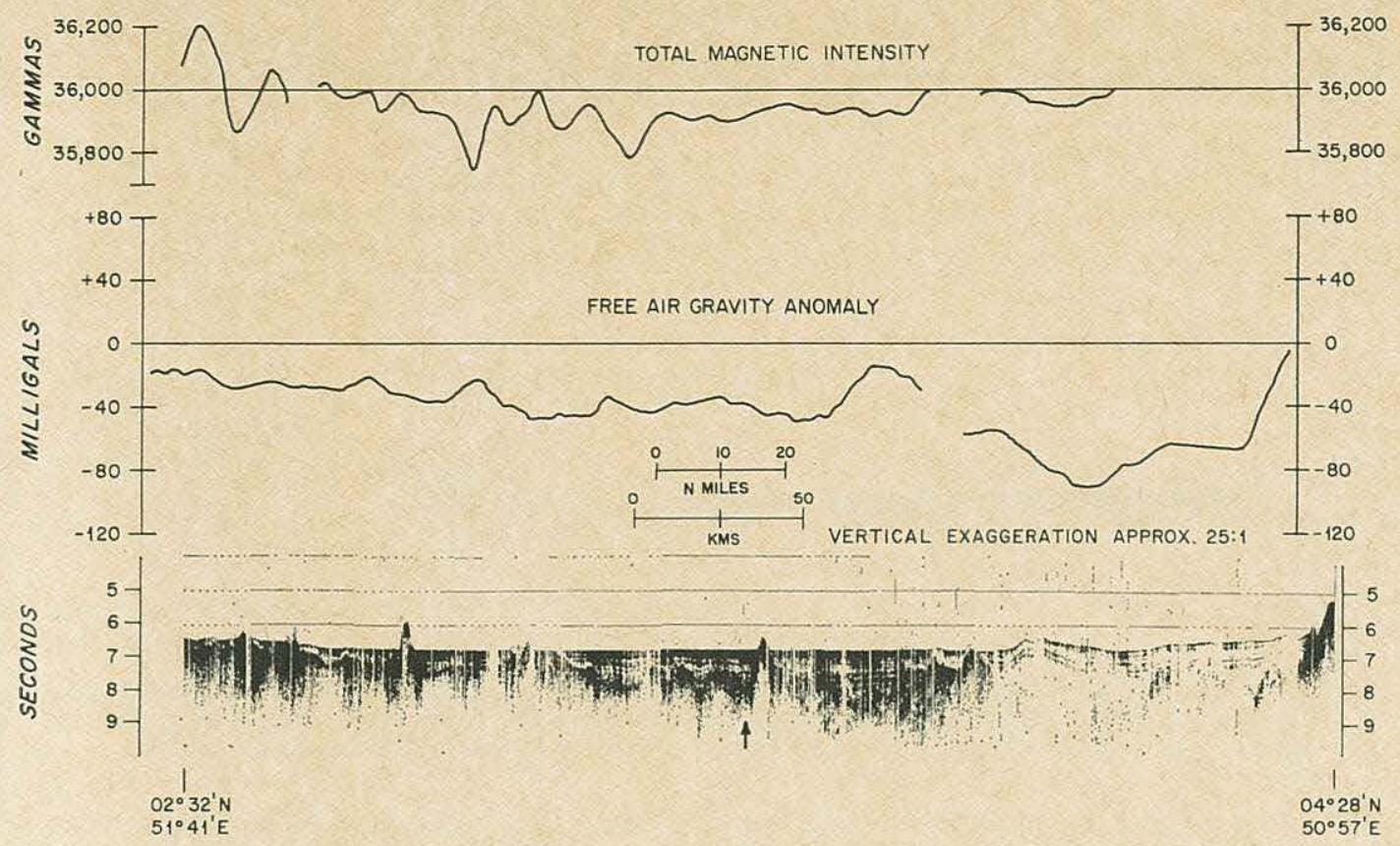

Fig. 4. Somali basin south of Chain ridge. Northeast-southwest crossing of Vema. Total magnetic intensity, free-air gravity anomaly, and seismic reflection profile. Arrow indicates intersection of profile 5 (Chain).
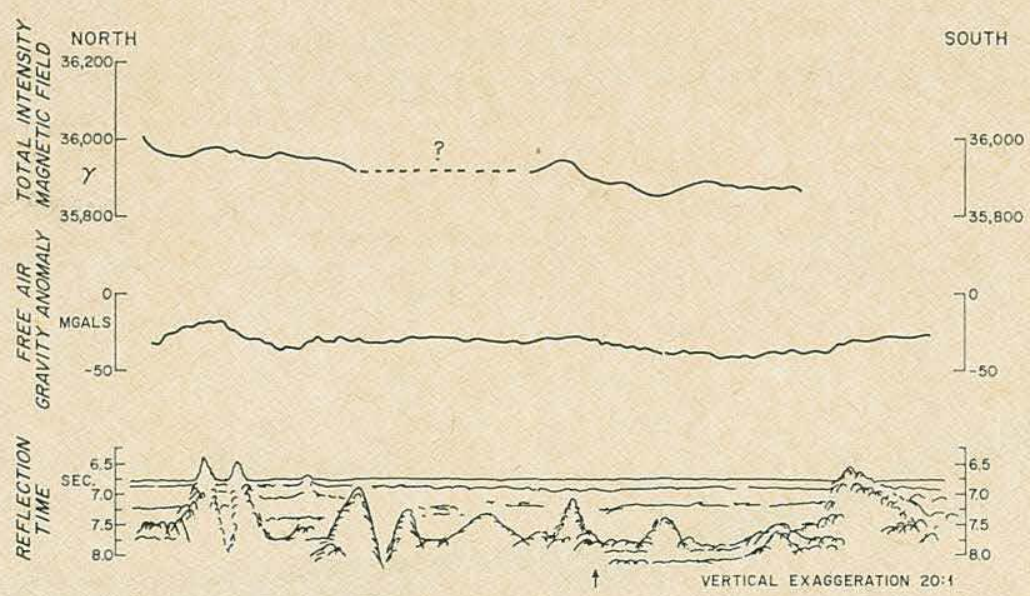

$$
\begin{array}{ll}
\text { O2. } 44^{\prime} \mathrm{N} N \\
52^{\circ} 26^{\prime} \mathrm{E}
\end{array}
$$

Fig. 5. Somali basin south of Chain ridge. Portion of north-south traverse of Chain. Total magnetic intensity, free-air gravity anomaly, and seismic reflection profile. Arrow indicates intersection of profile 4 (Vema). 


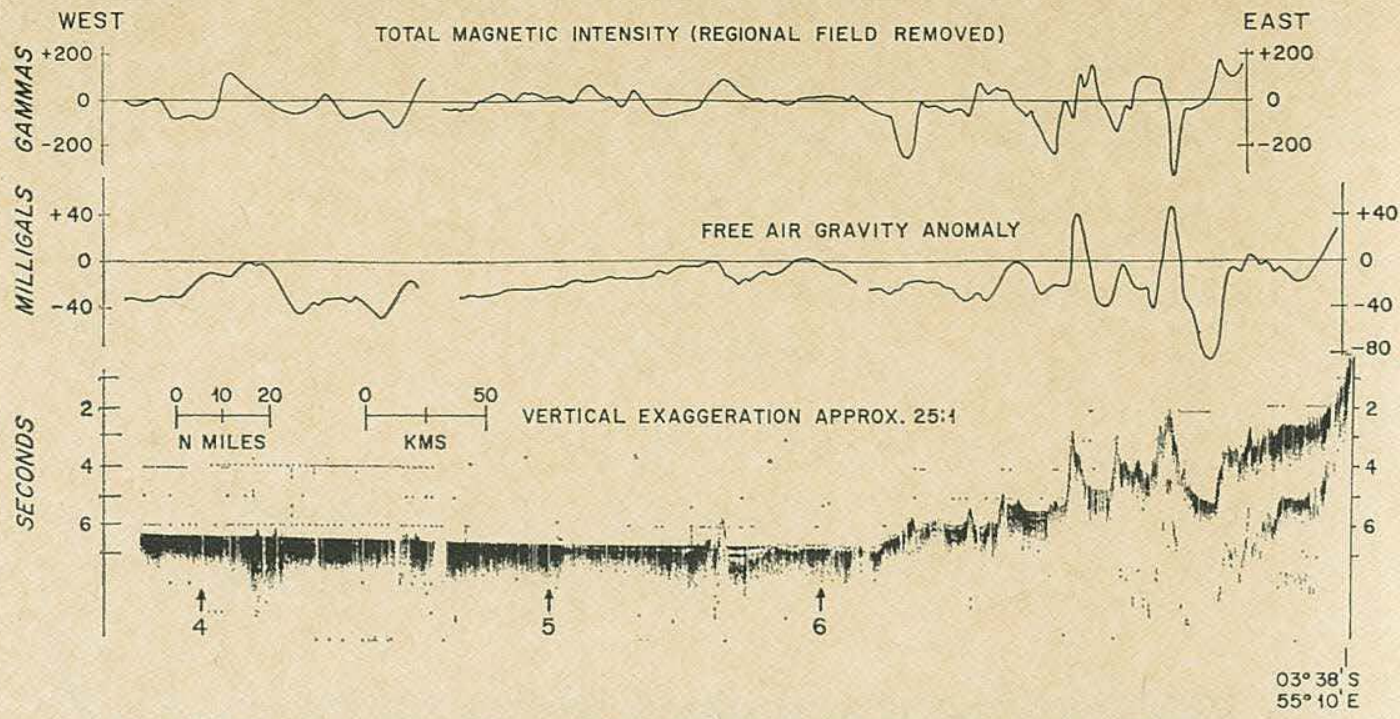

Fig. $6 a$. Somali basin, southern portion. Eastern part of Vema's crossing. Total magnetic intensity (regional field removed), free-air gravity anomaly, and seismic reflection profile. Numbers show projected positions of refraction profiles 4, 5, and 6 [Francis et al., 1966 ].

basement structure of the southern basin, with little or no accompanying variation in the gravity and magnetic profiles.

The southernmost profile runs almost due west across the basin. The Seychelles bank
(Figure 6a, right-hand side) slopes down steeply to a terrace about $50 \mathrm{~km}$ wide having a rough highly reflective surface almost devoid of sediment. The terrace terminates abruptly in a steep slope $\left(12^{\circ}\right)$, dropping into a 3650 -meter

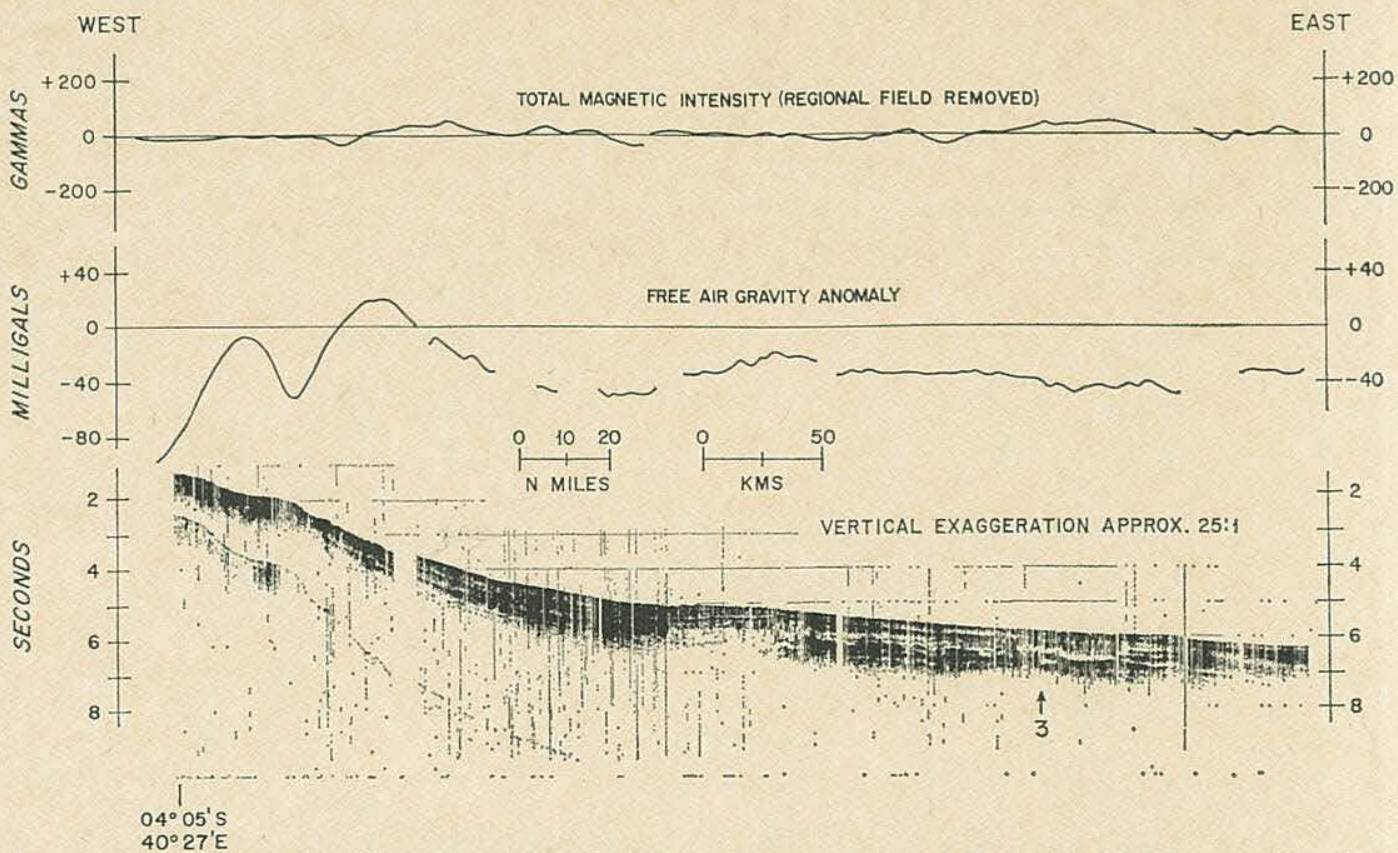

Fig. 6b. Somali basin, southern portion. Western part of Vema's crossing. Number shows projected position of refraction profile 3 [Francis et al., 1966]. 
valley. Continuing west, a few small peaks border sediment-filled pockets whose surfaces form terraces that step down gradually to the basin. An abyssal plain about $140 \mathrm{~km}$ in extent lies in the floor of the basin. The sediment sequence of the abyssal plain is not well defined, except in a pocket on the eastern side of an isolated steep hill near 6 in Figure $6 a$. From a point near 5 (Figure $6 a$ ) the bottom rises gradually from the abyssal plain to the continental shelf on the western side of the basin. The sediments on this slope are thick and clearly stratified.

In the deep part of the basin (near 4, Figure $6 a$ ), the gravity and magnetic anomalies suggest a shallow rough basement structure. The presence of isolated hills piercing the sediment confirms that basement is nowhere very deep.

Seven seismic refraction profiles were made in the southwestern basin and reported by Francis et al. [1966]. Three are close enough to the reflection profile to make comparisons of the results for the sedimentary section. The relative accuracies of the positions, shown in Figures $1,6 a$, and $6 b$, are of course subject to the errors inherent in comparing positions obtained by celestial fixes and dead reckoning. All the refraction profiles were oriented SSW-NNE, oblique to the line of the reflection profile, which crosses within $2 \mathrm{~km}$ of profile 6 on the eastern margin, lies about $8 \mathrm{~km}$ south of profile 5 and about $40 \mathrm{~km}$ south of profile 4 .

The comparison has been made by computing vertical reflection times for the wave velocity and layer thickness data of the refraction profiles, and direct reading of the seismicprofiler reflection times.

Table 1 presents the results for refraction profiles, 4, 5, and 6. On profile 4, which lies near the foot of the continental rise, 700 meters of $1.79-\mathrm{km} / \mathrm{sec}$ material were measured. The reflection profile, about $40 \mathrm{~km}$ to the south, shows clearly stratified sediment in the upper $0.7 \mathrm{sec}$ above a more acoustically transparent layer (not clearly shown on the reproduction of Figure $6 a$ ). The bottom of the stratified layer possibly corresponds to the top of the $2.5-\mathrm{km} / \mathrm{sec}$ layer. A deeper reflector at 1.3 sec is also observed on the original profiler records.

The uppermost sediment section indicated by the data of profile 5 and the reflection pro-
TABLE 1

\begin{tabular}{ccccc}
\hline Profile & $\begin{array}{c}V_{L}, \\
\mathrm{~km} / \mathrm{sec}\end{array}$ & $\begin{array}{c}T_{L}, \\
\mathrm{~km}\end{array}$ & $\begin{array}{c}t_{L}, \\
\mathrm{sec}\end{array}$ & $t_{\boldsymbol{p}}, \mathrm{sec}$ \\
\hline 4 & $\begin{array}{l}1.79 \\
2.49\end{array}$ & 0.7 & 0.8 & 0.7 \\
5 & $\begin{array}{c}1.91 \\
\text { (2.5) }\end{array}$ & 0.10 & 0.10 & 0.10 \\
6 & $\begin{array}{c}(1.8) \\
6.2\end{array}$ & 0.3 & 0.33 & 0.15 (average) \\
& & & & \\
\hline
\end{tabular}

$V_{L}$, wave velocity in $\mathrm{km} / \mathrm{sec}$, refraction measurement [Francis et al. 1966, p. 243].

$T_{L}$, layer thickness in $\mathrm{km}$, refraction measurement.

$t_{L}$, computed reflection time, using the relation $2 T_{L} / V_{L}$.

$t_{p}$, measured reflection time from profiler record.

file are comparable. The base of the thin $(0.1$ sec) transparent layer appears to be the top of a $2.5-\mathrm{km} / \mathrm{sec}$ layer. Below the transparent layer there are indistinct reflections, suggestive of stratified sediments, to a depth of $0.5 \mathrm{sec}$.

In the vicinity of refraction profile 6 , the reflection record shows a relatively thin veneer of sediment (average thickness about $0.15 \mathrm{sec}$ ), in a region of gently rolling bottom topography and moderately rough basement surface. The refraction profile thickness of 300 meters ( 0.33 sec) is based on an assumed sedimentary velocity of $1.8 \mathrm{~km} / \mathrm{sec}$. This difference in sediment thickness is not surprising in view of the basement surface roughness and the averaging nature of the refraction process.

The location of refraction profile $3\left(2^{\circ} 31^{\prime} \mathrm{S}\right.$, $44^{\circ} 56^{\prime} \mathrm{E}$ ) is $110 \mathrm{~km}$ north of the reflection line. However, comparison of the two shows that the depth of the deepest observed reflector of the stratified sequence of the rise is comparable to that of the top of the $2.5-\mathrm{km} / \mathrm{sec}$ velocity layer as identified by Francis et al. [1966].

\section{Discussion and Summary}

The deep floor of the entire western Somali basin is covered by abyssal plain sedimentation. Seismic reflection results show, however, that the northern and southern parts are very different. An abrupt change in depth to basement occurs across a line at about latitude $3^{\circ} 30^{\prime} \mathrm{N}$, which is very near the southern end of Chain ridge. 
The abyssal plain is most extensive in the northern area. Small abyssal hills intrude the plain deposits in the central region, and the plain is narrow and appears to pinch out to the south.

The northern portion is characterized by a sedimentary sequence $2 \mathrm{~km}$ or more thick, ponded between the continental rise of Africa, Chain ridge, and shallow basement to the south.

The clearly defined stratification in the upper part of the sedimentary sequence is probably the result of deposition by a long series of turbidity flows, the reflectors being interfaces of coarse material at the base of each flow. The underlying acoustically transparent layer contains fewer turbidity flows and less clastic material. The sharp change in character from transparent to strongly stratified sediment possibly resulted from uplift of the East African watershed with a consequent increase in the influx of more clastic material. The deepest reflector, because of its relative flatness and occasional stratification, is interpreted as a deep sedimentary layer.

The abrupt deepening of the deepest reflector (Figure 2, arrow) appears to be a fault. If the fault exists it must be older than the overlying sediments, because it does not extend upward into them. The faulting and the formation of the ridge on the western margin of the basin may be contemporaneous. The reflection profile suggests that the ridge was formed during deposition of the stratified and transparent sediment layers. It appears to have formed slowly, lifting on its slopes some of the sedimentary layers originally deposited on a level sea floor.

In contrast, the upper $0.50 \mathrm{sec}$ ( 500 meters) of sediments terminate abruptly against the western slope of Chain ridge, whereas the deeper layers have a slight upturn. This implies deposition of the upper sequence after the last uplift of the ridge. The gentle upturn of the deeper layers may be the result of a small uplift of the ridge subsequent to their deposition, or alternatively the upturn could have resulted from differential compaction of the sediment. Thus, it is possible that the entire sediment sequence seen on the profile of the basin postdates this ridge, and, if the date of $89.6 \pm 4.5$ m.y. determined for the dredged gabbro represents the age of Chain ridge, deposition of the sediment seen in the profiles started no earlier than the Cretaceous.

Matthews [1966, p. 176] suggests that Chain ridge is a continuation of the Owen fracture zone system; however, Heezen and Tharp [1964] interpret it as an isolated feature. The lack of change in sediment level on the two reflection profiles (Figures 2 and 3 ) that cross it suggests the ridge is not continuous with the Owen fracture zone. Profiles crossing the Owen fracture zone north of the Carlsberg ridge show that recent sediments are displaced along the fracture zone (J. Ewing, personal communication). In contrast, the profiles of Figures 2 and 3 show Chain ridge to be relatively a stable feature in late Tertiary and Quaternary times. It is obvious that the structural relation between the Chain ridge and Owen fracture zone is not clear and surveys farther north are required.

In the southwestern Somali basin, the continental rise and slope are covered with thick, well stratified sediments. Francis et al. [1966, p. 260] have correlated the results of two refraction profiles (2 and 3 ), on the rise west of longitude $45^{\circ} \mathrm{E}$, with the geological column at Lamu on the Kenya coast. They suggest that the material having $2.5-\mathrm{km} / \mathrm{sec}$ velocity is possibly consolidated sediment of Jurassic and Cretaceous age, laid down perhaps when the water depth in these areas was not so great. The soft sediments $(1.8 \mathrm{~km} / \mathrm{sec})$ probably started to form during the Tertiary.'

The reflection profiler results show stratified sediments to a depth of $1 \mathrm{~km}$ on the continental slope (Figure $6 b$ ). This section of sediment can be correlated with a layer having a velocity of $1.9 \mathrm{~km} / \mathrm{sec}$ observed by Francis et al. [1966] The reflection profile shows that the sequence continues without significant thinning into the deep basin. In the vicinity of refraction profile 4 it is overlain by a wedge of flat-lying sediment. This means that the top of the $2.5-\mathrm{km} /$ sec velocity layer lies deeper than the interpretation of the refraction profile suggests. The covering wedge of sediments is possibly more recent, Tertiary or later.

Acknowledgments. We wish to acknowledge the helpful cooperation of the officers and crews of R.V. Vema, Captain H. C. Kohler, and R.V. Chain, Captain C. A. Davis, and the assistance of the scientific members of both institutions who 
participated in the cruises. Professors C. L. Drake and J. E. Nafe provided constructive criticism during the preparation of this manuscript.

This work has been supported at the Woods Hole Oceanographic Institution by the Office of Naval Research under contract Nonr-4029(00) and the National Science Foundation under research grants GP-2370 and GA-283; and at Lamont Geological Observatory by the Office of Naval Research under contract Nonr-266(48) and the National Science Foundation under research grants G-22260 and 5538 .

\section{REFERENCES}

Admiralty Marine Science Publication 4, Bathymetric, magnetic, and gravity investigations, H.M.S. Owen, 1961-1962, London, 1963.

Admiralty Marine Science Publication 9, Bathymetric, magnetic, and gravity investigations, H.M.S. Owen, 1962-1963, London, 1966.

Anonymous, International Indian Ocean Expedition, R.R.S. Discovery cruise 2 report, 1963 , Dept. of Geophysics, Cambridge University, The Royal Society, London, 60 pp., 1964.

Bowin, C., R. Bernstein, R. Madigan, and E. Ungar, Improved shipboard geophysical dataprocessing system (abstract), Geol. Soc. Am. Special Paper, 82, 17, 1965.

Bunce, E. T., and J. B. Hersey, Continuous seismic profiles of the Outer ridge and Nares basin north of Puerto Rico, Bull. Geol. Soc. Am. $\gamma 7(8), 803-812,1966$.

Bunce, E. T., C. O. Bowin, and R. L. Chase, Preliminary results of the 1964 cruise of $R / V$ Chain to the Indian Ocean, Phil. Trans. Roy. Soc., London, A, 259, 218-226, 1966.

Ewing, J. I., and G. B. Tirey, Seismic profiler, $J$. Geophys. Res., 66 (9), 2917-2927, 1961.

Francis, T. J. G., D. Davies, and M. N. Hill, Crustal structure between Kenya and the Seychelles, Phil. Trans. Roy. Soc., London, A, 259, 240-261, 1966.

Heezen, B. C., and M. Tharp, Physiographic diagram of the Indian Ocean, Geological Society of America, 1964.

Hersey, J. B., Continuous reflection profiling, The Sea, vol. 3, pp. 47-72, John Wiley \& Sons (Interscience Publications), New York, 1963.

Matthews, D. H., A major fault scarp under the Arabian Sea displacing the Carlsberg ridge near Socotra, Nature, 198, 950-952, 1963.

Matthews, D. H., The Owen fracture zone and the northern end of the Carlsberg ridge, Phil. Trans. Roy. Soc. London, A, 259, 172-186, 1966.

Talwani, M., J. L. Worzel, and M. Landisman, Rapid gravity computations for two-dimensional bodies with application to the Mendocino submarine fracture zone, J. Geophys. Res., $64(1), 49-59,1959$.

(Received October 6, 1966.) 



\section{DISTRIBUTION LIST}

No. of

Copies Addressee

U. S. NAVY ACTIVITIES

Office of Naval Research

Department of the Navy

Washington, D. C. 20360

1 Attn: Code 408

$1 \quad 418$

$1 \quad 437$

2

1

Chief of Naval Operation

Navy Department

Washington, D. C. 20350

1 Attn: OP 95

1

1

1

1

1

1 Director, Office of Naval

Research Branch Office 495 Summer Street

Boston, Mass. 02210

1 Assistant Secretary of the Navy (Research and Development) Navy Department

Washington, D. C. 20350

1 : Director, Office of Naval Research Branch Office, New York Area Office 207 West 24th Street New York, New York 10011
No. of

Copies

Commander

Naval Ship Systems Command

Navy Department

Washington, D. C. 20360

1 Attn: SHIPS 03

1

1

1

1 Chief of Naval Material

Navy Department

Washington, D, C. 20360

Attn: DCNM/CND (Development)

1 Commander

Naval Air Systems Command

Navy Department

Washington, D. C. 20360

Attn: AIR 370E

1. Project Manager

Antisubmarine Warfare Systems

Navy Department

Washington, D. C. 20360

1 Director, Special Projects

Navy Department

Washington, D. C. 20360 SP -240

2 Commander

U.S. Naval Oceanographic Office

Washington, D. C. 20390

1 Director, Naval Research Lab.

Underwater Sound Reference Div.

P. O. Box 8337

Orlando, Florida 32806 
No. of

Copies Addressee

Director

U.S. Naval Research Laboratory

Washington, D. C. 20390

1 Attn: Code 2021

$6 \quad 2027$

$1 \quad 5500$

$1 \quad 5510$

2 Commanding Officer and Director U. S. Navy Electronics Laboratory San Diego, California 92152

1 Commander (Code 753)

U. S. Naval Ordnance Test Station China Lake, California

Attn: Technical Library 93557

1 U. S. Naval Ordnance Test Station Pasadena Annex

3202 East Foothill Boulevard

Pasadena, California 91107

Attn: Pasadena Annex Library

2 Commanding Officer

U. S. Naval Ordnance Laboratory White Oak

Silver Spring, Maryland 20910

1 Commanding Officer

U. S. Naval Underwater Weapons Systems Engineering Center

Newport, Rhode Island 02844

1 Commanding Officer

U. S. Naval Air Development Center Johnsville, Pennsylvania 18974

1 Commanding Officer and Director U. S. Navy Mine Defense Laboratory Panama City, Florida 32402
No. of

Copies

Addressee

1. Librarian

U. S. Naval Postgraduate School

Monterey, California 93940

1 Systems Analysis Group

Undersea Warfare Research and

Development Council

Room 5-224

U. S. Naval Ordnance Laboratory

White Oak

Silver Spring, Maryland 20910

2 Commanding Officer and Director

U. S. Navy Underwater Sound Lab.

Fort Trumbull

New London, Connecticut 06321

OTHER U.S. GOVERNMENT AGENCIES

20 Defense Documentation Center

Cameron Station

Alexandria, Virginia 22314

1 Director

Bureau of Commercial Fisheries

Biological Laboratory

U.S. Fish and Wildlife Service

Woods Hole, Massachusetts 02543

2 Commanding Officer and Director Naval Ship Research and Development Center (Code 560)

Washington, D. C. 20007 
No. of

Copies Addressee

1 Chief, Evaluation and Reports

Division of Water Pollution Surveillance

Federal Water Pollution Control Administration

Department of the Interior

1014 Broadway

Cincinnati 2, Ohio 45202

1 Office of Naval Research

Project Officer

U. S. Navy Sofar Station

APO 856

New York, New York 09856

1 AFETR (ETLLG-1)

(For Technical Library,

$$
\text { MU-135) }
$$

Patrick AFB, Florida 32925

1 Commander, AntiSubmarine Force

U. S. Atlantic Fleet

Norfolk, Virginia 23511

1 Commander, AntiSubmarine Force

U. S. Pacific Fleet

FPO San Francisco, Calif. 96610

1 Commander Submarine Force

U. S. Atlantic Fleet

Norfolk, Virginia 23511

1 Commanding Officer and Director

ASW Tactical School

U. S. Atlantic Fleet

Norfolk, Virginia 23511
No. of

Copies

$\underline{\text { Addressee }}$

1 Commander Submarine Force

U. S. Pacific Fleet

FPO

San Francisco, California 96610

1 Commander Submarine Development Group TWO

FPO New York, New York

1 U. S. Naval Applied Science

Laboratory, Code 9360

U. S. Naval Base

Brooklyn, New York 11251

1 Commander Destroyer Development Group TWO

FPO New York, New York 09051

U.S. LABORATORIES AND UNIVERSITIES

(except those of U.S. Government)

1 Advanced Research Projects Agency

Pentagon

Washington, D. C. 20360

Attn: Nuclear Test Detection Office

Dr. G. P. Woollard, Director

Hawaii Institute of Geophysics

University of Hawaii

Honolulu, Hawaii 96822

1 Director

Hudson Laboratories

145 Palisade Street

Dobbs Ferry, New York 10522 
No. of

Copies Addressee

1 Fluid and Solid Mechanics Laboratory Institute of Science and Technology Post Office Box 618

Ann Arbor, Michigan

1 Institute of Defense Analyses Communications Research Division Von Neumann Hall

Princeton, New Jersey

1 Library

Lamont Geological Observatory

Columbia University

Palisades, New York 10964

1 Director

Marine Physical Laboratory of the

Scripps Institution of Oceanography San Diego 52, California 92038

1 National Academy of Sciences

National Research Council

Committee on Oceanography

2101 Constitution Avenue

Washington, D. C. 20418

1 Dr. H. S. Hayre

Prof., Electrical Engineering

University of Houston

Houston 4; Texas

1 Ordnance Research Laboratory

Pennsylvania State University

University Park, Pennsylvania 16801
No. of

Copies Addressee

1 Director, Marine Labaratory

University of Miami

1 Rickenbacker Causeway

Virginia Key

Miami, Florida 33149

1. Director

Narragansett Marine Laboratory

University of Rhode Island

Kingston, Rhode Island 02881

1 Director

Defense Research Laboratory

University of Texas

Austin, Texas

1 Director

Department of Oceanography

Texas $\mathrm{A}$ and $\mathrm{M}$ University

College Station, Texas 77843

1 Applied Physics Laboratory

University of Washington

1013 East 40th Street

Seattle, Washington 98105

\section{INDUSTRY}

1 Bell Telephone Laboratories, Inc. Whippany, New Jersey 07981

Attn: Mr. C. F. Wiebusch, Div.

1 Daystrom Electric

Division of Daystrom, Inc.

753 Main Street

Poughkeepsie, New York 
No. of

Copies Addressee

\section{FOREIGN ACTIVITIES}

1 SACLANT ASW RESEARCH CENTER

APO 09019

New York, New York

1 Bermuda Biological Station

St. George's West, Bermuda

Attn: Mrs. Leida Piip, Librarian

Via: ONR (Code 466)

Washington, D. C. 20360

1 National Institution of Oceanography

Wormley

Godalming, Surrey, ENGLAND

Attn: Library

1 Pacific Oceanographic Group

Nanaimo, British Columbia

1 Seyir ve Hidrografi Dairesi

Cubuklu-Istanbul, Turkey

Via: (1) ONR (Code 466)

Washington, D. C. 20360

(2) Officer in Charge

Schools Advisory Detachment

JUSMMAT APO 380

New York, New York 09380

1 Instituto Nacional de Oceanografia

Director

Rivadavia 1917 - R25

Buenos Aires, Argentina 


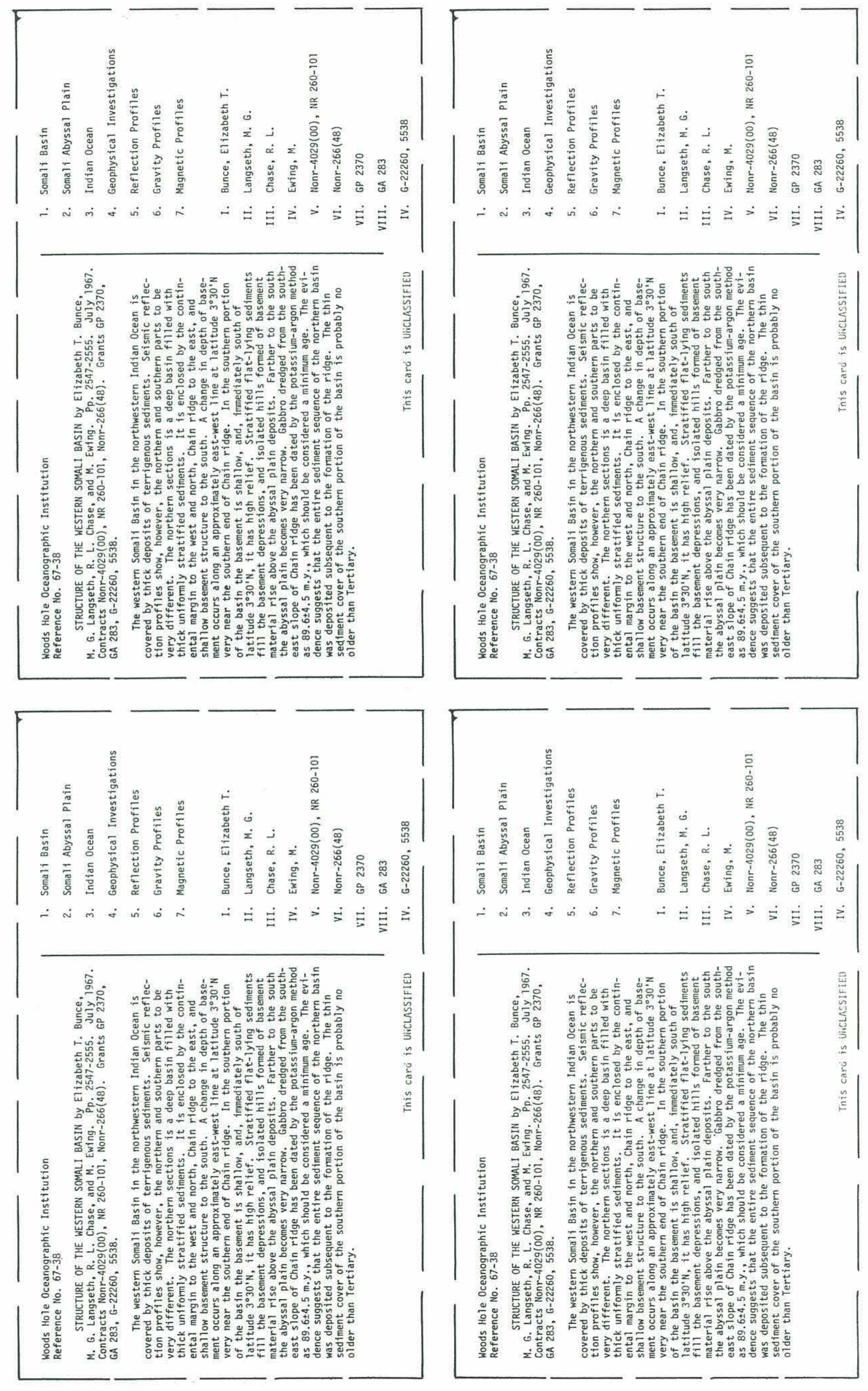

